\title{
PERBEDAAN EFEKTIFITAS PEMBERIAN BUAH KURMA DAN DAUN KATUK TERHADAP KELANCARAN ASI PADA IBU MENYUSUI UMUR 0-40 HARI DI KOTA KEDIRI
}

\author{
Siti Aminah', Wahyu Purwaningsih ${ }^{2}$ \\ ${ }^{1,2}$ Program Studi Kebidanan, Fakultas Ilmu Kesehatan, Universitas Kadiri \\ siti_aminahkdr@yahoo.co.id
}

\begin{abstract}
Breastfeeding has benefit and nutrient that are good for baby's health, especially for the 0-6 months baby. On February 2017 from 55 breastfeeding mothers at Sukorame Community Health Center (Puskesmas), there are 32 mothers $(17,6 \%)$ having problem on their breast milk production. The aim of this study is distinguishing the effect of palm fruit and katuk (Sauropus androginus) leaves on breastmilk production on 0-40 days nursing mothers at Sukorame Community Health Center (Puskesmas). This research uses Pre Experimental design with One Group Pre Test Post Test Design. This study used 32 mothers as sample and taken with Purposive Sampling technique. The data analyzed using Wilcoxon test and Mann Whitney test. The result shows that after giving the palm fruit to the respondents, $50 \%$ breastfeeding mothers experienced better breastmilk production and after giving katuk (Sauropus androginus) leaves, 93,8\% breastfeeding mothers experienced better breastmilk production. Wilcoxon test result shows p-value 0,005 for the effect of palmfruit and p-value 0,000 for the effect of katuk (Sauropus androginus) which indicates there is significant effect after treatments.Mann Whitney test result shows p-value 0,007> a 0,05 that there is difference effect on breastfeeding mothers after consuming palm fruit and katuk (Sauropus androginus) leaves. The result shows that consumed katuk leaves had better effect for breastfeeding mothers. Besides, katuk leaves give many benefit and help breastfeeding mothers experience better breastmilk production.
\end{abstract}

Keywords: palm fruit, leaves and smoothness ASI katuk

\begin{abstract}
ABSTRAK
ASI memiliki manfaat dan kandungan gizi yang baik bagi kesehatan bayi pada usia 0 sampai 6 bulan. ASI akan cukup memenuhi kebutuhan pertumbuhan dan perkembangan neonatus dan bayi normal sampai usia 6 bulan. Di daerah Sukorame Kota Kediri pada bulan Februari tahun 2017 dari 55 orang ibu menyusui terdapat 32 orang $(17,6 \%)$ ibu menyusui dengan asi tidak lancar. Tujuan penelitian ini adalah untuk mengetahui perbedaan efektifitas pemberian buah kurma dengan daun katuk terhadap kelancaran ASI pada ibu menyusui 0-40 hari. Desai penelitian ini menggunakan Pre experimental dengan metode One Group Pre Test Post Test Desain. Sampel dalam penelitian ini adalah 32 orang di ambil dengan menggunakan teknik purposive sampling. Analisis data menggunakan uji Wilcoxon dan untuk mengetahui perbedaan efektifitas menggunakan uji Mann Whitney. Hasil penelitian sebelum diberikan kurma dan daun katuk sama-sama berada pada kategori tidak lancar yaitu sebanyak 16 orang (100\%). Setelah mengkonsumsi kurma setengahnya (50\%) mengalami asi lancar. Sedangkan yang mengkonsumsi daun katuk (93,8\%) mengalami asi lancar. Hasil uji Wilcoxon untuk konsumsi buah kurma di dapatkan p-value 0,005 dan untuk konsumsi daun katuk p-value 0,000 yang artinya p value $<0,05$ sehingga dapat disimpulkan ada perbedaan sebelum dan sesudah perlakuan. Hasil uji Mann Whitney menunjukkan $\mathrm{p}$ value $0.007>\alpha 0.05$ sehingga dapat disimpulkan ada perbedan efektifitas antara pemberian buah kurma dan daun katuk, dimana daun katuk lebih efektif terhadap kelancaran ASI. Berdasarkan hasil penelitian ,diharapkan ibu menyusui mengkonsumsi buah kurma dan daun katuk selain mudah di dapat juga banyak mengandung manfaat dan dapat membantu memperlancar pengeluaran ASI pada ibupost partum.
\end{abstract}

Kata kunci :Buah kurma, Daun katuk, kelancaran ASI, ibu menyusui 


\section{PENDAHULUAN}

Pengeluaran ASI dikatakan lancar bila produksi ASI berlebihan yang di tandai dengan ASI akan menetes dan akan memancar deras saat di hisap bayi (Purwanti, 2009). Pada hari pertama, bayi cukup di susukan selama 10-15 menit, untuk merangsang produksi ASI dan membiasakan putting susu di hisap oleh bayi. Bayi yang mendapatkan ASI memadai umumnya lebih tenang, tidak rewel dan dapat tidur pulas. Tanda pasti bahwa ASI memadai dapat di lihat pada penambahan berat badan bayi yang baik. Dalam keadaan normal usia 0-5 hari biasanya berat badan bayi akan menurun. Setelah usia 10 hari berat badan bayi akan kembali seperti lahir, secara alamiah ASI di produksi dalam jumlah yang sesuai dengan kebutuhan bayi (Wulan, 2011).

Data Badan Kesehatan Dunia (WHO) tahun 2016 masih menunjukkan rata-rata angka pemberian ASI eksklusif di dunia baru berkisar 38 persen. Di Indonesia meskipun sejumlah besar perempuan (96\%) menyusui anak mereka dalam kehidupan mereka, hanya $42 \%$ dari bayi yang berusia di bawah 6 bulan yang mendapatkan ASI eksklusif. Pada saat anak-anak mendekati ulang tahunnya yang ke dua, hanya 55\% yang masih diberi ASI (Pramita, 2017).

Hasil pemantauan status gizi 2016 menyebut bahwa pencapaian ASI eksklusif di Indonesia baru sekitar 54 persen. Itu berarti masih ada 46 persen bayi lainnya yang tidak mendapat ASI eksklusif dengan berbagai alas an (Inriani, 2017). Berdasarkan data Susenas (Survei Sosial Ekonomi Nasional) 2013 presentase cakupan pemberian ASI Eksklusif di penelitian di inggris menyebutkan bahwa perbedaan rata IQ bayi yang diberikan ASI lebih tinggi dibandingkan bayi tanpa ASI (Muktamar, 2009).

Menurut Depkes RI (2009) ibu yang memberikan ASI secara eksklusif hingga saat ini masih rendah, yaitu kurang dari $2 \%$ dari jumlah total ibu melahirkan. Tahun 2015 cakupan ASI Eksklusif sebesar 498 Orang $(65,5 \%)$ dengan cakupan tertinggi yaitu $83,0 \%$ diperoleh puskesmas Ngeletih , puskesmas Sukorame menempati urutan ke 6 yaitu 65,5\% (Dinas kesehatan kabupaten Kediri, 2015).

Berdasarkan hasil survey awal yang dilakukan di wilayah kerja Puskesmas Sukorame Kota Kediri bulan Januari tahun 2017 didapatkan jumlah wanita menyusui umur 0-40 hari sebanyak 55 orang, sedangkan ibu yang mengalami ASI tidak lancar pada usia menyusui $0-40$ hari sejumlah 32 orang $(17,6 \%)$. Faktor penyebab ketidaklancaran ASI, dapat di picu oleh keadaan gizi ibu, pengalaman / sikap ibu terhadap menyusui, keadaan emosi, keadaan payudara, peran masyarakat dan pemerintah (Wulan, 2011).

Mengonsumsi kurma dapat membantu melancarkan ASI karena kandungan didalamnya, ibu hamil atau menyusui sangat dianjurkan mengonsumsi buah ini (Hammad, 2014). 100 gram kurma yang dikonsumsi akan menghasilkan 284 kalori. Kurma memiliki keistimewaan mudah dicerna sehingga bisa mencapai darah dalam waktu relative singkat dan bisa dimanfaatkan oleh seluruh organ tubuh, khususnya otak karena unsure gula merupakan nutrisi penting bagi otak. Adapun sebagai berikut beberapa manfaat kurma untuk kesehatan tubuh (Hammad, 2014).

Selain buah kurma, ada juga Daun Katuk yang dipercaya melancarkan ASI. Daun katuk banyak digunakan sebagai bahan fortifikasi pada produk makanan yang diperuntukkan bagi ibu menyusui. Konsumsi Daun Katuk oleh ibu menyusui dapat memperlama waktu menyusui (Santoso dan Anne Lies Ranti, 2009). Kehebatan Daun Katuk secara empiris bukan tanpa penjelasan ilmiah. Daun Katuk memiliki kandungan Laktagagum, steroid, serta polifenol yang mampu meingkatkan kadar prolaktin yang dapat meningkatkan produksi Asi (Andareto, 2015).

\section{METODE PENELITIAN}

Penelitian ini merupakan penelitian pre esperimental dengan pensdekatan One Group Pre Test Post Test Desain. Populasi dalam penelitian ini adalah seluruh ibu menyusui diwilayah kerja puskesmas Sukorame tahun 2017 sejumlah 32 responden. Sampel dalam penelitian ini menggunakan total populasi yang di bagi menjadi 2 kelompok, masingmasing kelompok berjumlah 16 responden, pengambilan sampel menggunakan teknik purposive sampling. Variabel independen dalam penelitian ini adalah pemberian buah kurma dan daun katuk untuk variabel dependennya adalah kelancaran produksi ASI. Pemberian buah kurma setiap hari sebanyak 100 gram atau 8 butir di konsumsi selama 7 hari, untuk pemberian daun katuk sebanyak 100 gram di rebus dengan air 300 cc di konsumsi setiap hari selama 7 hari kemudian 
dilakukan penilaian tentang kelancaran produksi ASI menggunakan lembar observasi. Analisis data untuk mengetahui adanya perbedaan masing - masing kelompok setelah perlakuan menggunakan uji Wilcoxon dan untuk mengetahui perbedaan efektifitas menggunakan uji Mann Whitney

\section{HASIL PENELITIAN}

Kelancaran ASI ibu sebelum dan sesudah pemberian buah kurma

Tabel 1. Tabulasi Kelancaran ASI sebelum dan sesudah pemberian buah kurma Pada Ibu Menyusui

\begin{tabular}{|l|c|l|c|}
\hline \multicolumn{2}{|c|}{ Sesudah diberi Buah Kurma } & \multicolumn{2}{c|}{ Sesudah diberi Daun Katuk } \\
\hline Negative Ranks & $0^{\mathrm{a}}$ & Negative Ranks & $0^{\mathrm{a}}$ \\
\hline Positive Ranks & $8^{\mathrm{b}}$ & Positive Ranks & $15^{\mathrm{b}}$ \\
\hline Ties & $8^{\mathrm{c}}$ & Ties & $1^{\mathrm{c}}$ \\
\hline Total & 16 & Total & 16 \\
\hline P. value $=0,007$ & $\alpha=0,05$ \\
\hline
\end{tabular}

Berdasarkan data pada tabel 1 kelancaran ASI sebelum pemberian buah kurma seluruhnya (100\%) tidak lancar, sesudah pemberian buah kurma setengahnya $(50,0 \%)$ ASI ibu tidak lancar dan setengahnya (50,0\%) ASI ibu lancar.

\section{Kelancaran ASI ibu sebelum dan sesudah} pemberian daun katuk
Hasil uji statistik Willcoxon didapatkan $p$ value sebesar 0,005 atau $p<\alpha(0,05)$, maka $\mathrm{H}_{0}$ ditolak dan $\mathrm{H}_{1}$ diterima yang berarti ada efektifitas sebelum dan sesudah pemberian buah kurma terhadap kelancaran ASI pada ibu Menyusui.

Tabel 2. Tabulasi Kelancaran ASI sebelum dan sesudah pemberian daun katuk Pada Ibu menyusui

\begin{tabular}{|l|c|c|c|c|}
\hline & \multicolumn{2}{|l|}{ Sebelum pemberian daun katuk } & \multicolumn{2}{c|}{$\begin{array}{c}\text { Sesudah pemberian daun } \\
\text { katuk }\end{array}$} \\
\hline & $\mathrm{F}$ & $\%$ & $\mathrm{~F}$ & $\%$ \\
\hline Tidak lancar & 16 & 100 & 1 & 63,3 \\
\hline Lancar & 0 & 0 & 15 & 93,8 \\
\hline Total & 16 & 100 & 16 & 100 \\
\hline \multicolumn{2}{|c|}{ P value $: 0,000 \quad \alpha=0,05$} \\
\hline
\end{tabular}

Berdasarkan data yang diperoleh pada tabel 2 kelancaran ASI sebelum pemberian daun katuk seluruhnya $(100 \%)$ tidak lancar, sesudah pemberian daun katuk sebesar $63,3 \%$ ASI ibu tidak lancar dan sebesar 93,8\% ASI ibu lancar.
Hasil uji statistik Willcoxon didapatkan $p$-value sebesar 0,000 atau $p<\alpha(0,05)$, maka $\mathrm{H}_{0}$ di terima dan $\mathrm{H}_{1}$ ditolak yang berarti ada efektifitas sebelum dan sesudah pemberian daun katuk terhadap kelancaran ASI pada ibu Menyusui. 


\section{Analisis Perbedaan Efektifitas Sesudah Pemberian buah kurma dan Sesudah Pemberian daun katuk Terhadap Peningkatan Kelancaran ASI Pada Ibu Menyusui}

Tabel 3. Perbedaan Efektifitas Sesudah Pemberian buah kurma dan Sesudah Pemberian daun katuk Terhadap Peningkatan Kelancaran ASI Pada Ibu Menyusui

\begin{tabular}{|l|c|c|c|c|}
\hline & \multicolumn{2}{|c|}{$\begin{array}{c}\text { Sebelum pemberian buah } \\
\text { kurma }\end{array}$} & \multicolumn{2}{c|}{ Sesudah pemberian buah kurma } \\
\hline & $\mathrm{F}$ & $\%$ & $\mathrm{~F}$ & 50,0 \\
\hline Tidak lancar & 16 & 100 & 8 & 50,0 \\
\hline Lancar & 0 & 0 & 8 & 100 \\
\hline Total & 16 & 100 & 16 & \\
\hline P value $: 0,005$ & $\alpha=0,05$
\end{tabular}

Hasil uji statistik Man-Whitney didapatkan p-value sebesar 0,007 atau $p<\alpha(0,05)$, maka $\mathrm{H}_{0}$ ditolak dan $\mathrm{H}_{1}$ diterima yang berarti terdapat perbedaan efektivitas pemberian buah kurma dan daun katuk terhadap kelancaran ASI pada ibu menyusui di Posyandu Desa Pojok Wilayah Kerja Puskesmas SukorameKota Kediri Tahun 2017.

\section{PEMBAHASAN}

Kelancaran ASI sebelum dan sesudah mengkonsumsi buah kurma pada ibu menyusui 0-40 hari

Berdasarkan data pada tabel 1 kelancaran ASI sebelum pemberian buah kurma seluruhnya (100\%) tidak lancar, sesudah pemberian buah kurma setengahnya $(50,0 \%)$ ASI ibu tidak lancar dan setengahnya (50,0\%) ASI ibu lancar.

Faktor yang memefektifitasi pembentukan ASI adalah makanan, ketenangan jiwa dan pikiran, perawatan payudara, anatomis payudara, faktor fisiologi, pola istirahat, umur kehamilan saat melahirkan dan konsumsi rokok dan alkohol (Wiji, 2013).

Kurma memiliki keistimewaan mudah dicerna sehingga bisa mencapai darah dalam waktu relative singkat dan bisa dimanfaatkan oleh seluruh organ tubuh, khususnya otak karena unsur gula merupakan nutrisi penting bagi otak. Adapun sebagai berikut beberapa manfaat kurma untuk kesehatan tubuh yaitu menambah energi, melancarkan sistem pencernaan, mengecilkan rahim, dan melancarkan ASI (Hammad, 2014).

Kurma memiliki berbagai macam gizi, dan hormon. dimana buah kurma memiliki Hormon patuchin yang berfungsi untuk mengikat rahim dan otot rahim sehingga dapat membantu
Dari hasil dapat disimpulkan bahwa yang lebih efektif adalah daun katuk karena dari 16 jumlah responden terdapat 15 orang yang mengalami ASI lancer

mengurangi pendarahan pasca melahirkan, hormon ini juga akan membantu memacu kontraksi di pembuluh darah vena yang ada di sekitar payudara ibu, sehingga memacu kelenjar air susu untuk menghasilkan air susu ibu.

Selain itu, buah Kurma juga memiliki Hormon Oksitosin yang di hasilkan oleh neurohipofisa. Hormon oksotosin di alirkan melalui darah menuju payudara, hormon ini akan memacu kontraksi pada pembuluh darah vena yang ada di sekitar payudara ibu, sehingga memacu kelenjar air susu untuk memproduksi ASI (Satuhu, 2010).

Penelitian oleh Sulieman (2012) menunjukkan bahwa kurma merupakan salah satu makanan yang disarankan untuk di konsumsi oleh ibu menyusui dikarenakan kurma mengandung zat yang dapat menstimulasi ASI dan memberikan ketenangan. Hasil penelitian oleh Natalia Desy Putriningtyas, 2016 Sari kurma dan susu kental manis yang diberikan pada ibu yang menyusui eksklusif dapat meningkatkan berat badan bayi usia $0-5$ bulan. 


\section{Kelancaran ASI sebelum dan sesudah mengkonsumsi daun katuk pada ibu menyusui 0-40 hari}

Berdasarkan data yang diperoleh pada tabel 2 kelancaran ASI sebelum pemberian daun katuk seluruhnya (100\%) tidak lancar, sesudah pemberian daun katuk sebesar 63,3\% ASI ibu tidak lancar dan sebesar 93,8\% ASI ibu lancar.

Menyusui adalah salah satu komponen dari proses reproduksi.Laktasi atau menyusui merupakan proses integral dari daur reproduksi dan mempunyai dua pengertian yaitu produksi dan pengeluaran ASI. Keduanya harus sama baiknya. Menyusui setiap dua-tiga jam akan menjaga produksi ASI tetap tinggi. Untuk wanita pada umumnya, menyusui atau memerah ASI delapan kali dalam 24 jam akan menjaga produksi ASI tetap tinggi pada masa-masa awal menyusui, khususnya empat bulan pertama (Gartner LM, 2005).

Ketidak lancaran pemberian ASI dapat di atasi dengan terapi farmakologis dan nonfarmakologis, salah satu jenis terapi non farmakologis adalah dengan pemberian daun katuk. Daun katuk dapat di gunakan sebagai sayur dan dapat juga di gunakan sebagai jamu. Katuk (sauropus adrogynus) adalah sejenis daundaunan yang seringkali dijadikan sebagai sayuran. Tanaman ini merupakan salah satu suku dari phyllanthaceae. Tidak banyak orang yang mengenal dan mengetahui bahwa tanaman ini sebenarnya dapat menjadi sayuran yang dikonsumsi sehari-hari (Suseno, 2013).

Daun katuk dipercaya sangat manjur digunakan sebagai obat-obatan herbal. Hal tersebut dikarenakan daun katuk mengandung berbagai macam zat yang dibutuhkan tubuh seperti vitamin $\mathrm{K}$, vitamin $\mathrm{A}$, vitamin $\mathrm{B}$, vitamin C (Suseno, 2013). Tidak hanya itu saja, katuk juga mengandung hampir 7\% protein, 19\% serat kasar. Daun ini kaya vitamin K, selain provitamin A (beta karoten), $\mathrm{B}$ dan $\mathrm{C}$, mineral yang dikandungnya adalah kalsium(hingga 2,8\%), besi, kalium, fosfor, dan magnesium. Warna daunnya hijau gelap karena kadar klorofil yang cukup tinggi bila dibandingkan dengan daundaun lainnya (Agoes, 2010).

Daun katuk mengandung steroid dan polifenol yang dapat meningkatkan kadar prolaktin. Pada pemberian daun katuk ditemukan peningkatan kadar hormon steroid adrenal. Kadar prolaktin yang tinggi akan meningkatkan, mempercepat dan memperlancar produksi ASI. Daun katuk juga mengandung alkaloid, sterol, flavonoid dan tannin.
Selain itu, daun katuk juga memiliki Laktagagum yaitu zat yang mampu meningkatkan dan melancarkan produksi ASI, dari hasil penelitian yang telah di lakukan di desa pojok didapatkan hasil bahwa pemberian daun katuk sangat efektif untuk ibu menyusui, hal ini sesuai dengan hasil penelitian yang menyatakan bahwa kelancaran ASI sebelum pemberian daun katuk seluruhnya tidak lancar atau sebanyak 16 responden dan sesudah pemberian daun katuk terdapat 1 orang responden atau sebesar ASI ibu tidak lancar dan sebanyak 15 responden atau sebesar ASI ibu lancar. Hal ini menunjukkan bahwa hampir seluruhnya terjadi peningkatan kelancaran ASI sesudah pemberian daun katuk.

Ibu menyusui yang mengkonsumsi daun katuk, sebanyak $70 \%$ terjadi peningkatan produksi ASI hingga melebihi kebutuhan bayinya. Sedangkan pada ibu yang tidak mengkonsumsi daun katuk, hanya $6,7 \%$ yang mengalaimi kenaikan produksi ASI (Suwanti dan Kuswati, 2016). Ibu menyusui yang mengkonsumsi ekstrak daun katuk dengan dosis $2 \mathrm{x}$ dan $3 \mathrm{x}$ sehari memiliki pengaruh yang bermakna terhadap kadar hormon prolaktin dalam darah (Nurjanah S dan Kamariyah N, 2017). Produksi ASI meningkat karena dalam daun katuk mengandung alkaloid dan sterol (Aulianova dan Tara, 2016)

\section{Perbedaan efektifitas pemberian buah kurma dan daun katuk terhadap kelancaran ASI pada ibu menyusui 0-40 hari}

Hasil uji statistic Man - Whitney didapatkan $p$-value sebesar 0,007 atau $p<\alpha$ $(0,05)$, maka $\mathrm{H}_{0}$ ditolak dan $\mathrm{H}_{1}$ diterima yang berarti ada perbedaan efektifitas sesudah pemberian daun katuk dan sesudah pemberian buah kurma terhadap kelancaran ASI pada ibu menyusu, dimana pemberian daun katuk lebih efektif dalam meningkatkan kelancaran ASI dibandingkan pemberian buah kurma.

Kurma memiliki berbagai macam gizi, dan hormon. dimana buah kurma memiliki Hormon patuchinyang berfungsi untuk mengikat rahim dan otot rahim sehingga dapat membantu mengurangi pendarahan pasca melahirkan, hormon ini juga akan membantu memacu kontraksi di pembuluh darah vena yang ada di sekitar payudara ibu, 
sehingga memacu kelenjar air susu untuk menghasilkan air susu ibu. Selain itu buah Kurma juga memiliki Hormon Oksitosin yang di hasilkan oleh neurohipofisa. Hormon oksotosin di alirkan melalui darah menuju payudara, hormon ini akan memacu kontraksi pada pembuluh darah vena yang ada di sekitar payudara ibu, sehingga memacu kelenjar air susu untuk memproduksi ASI (Satuhu, 2010).

Daun katuk mengandung steroid dan polifenol yang dapat meningkatkan kadar prolaktin. Pada pemberian daun katuk ditemukan peningkatan kadar hormon steroid adrenal. Kadar prolaktin yang tinggi akan meningkatkan, mempercepat dan memperlancar produksi ASI. Daun katuk juga mengandung alkaloid, sterol, flavonoid dan tannin.Selain itu, daun katuk juga memiliki Laktagagum yaitu zat yang mampu meningkatkan dan melancarkan produksi ASI.

Selain memperlancar produksi ASI seperti yang dikenal selama ini, daun katuk juga kaya senyawa yang dapat meningkatkan mutu dan jumlah sperma, termasuk membangkitkan vitalitas seksual. Daun katuk dipenuhi senyawa fitokimia berkhasiat obat. Daun katuk merupakan sayuran multikasiat bagi kesehatan tubuh.

Walaupun kedua teknik tersebut dapat meningkatkan produksi ASI, namun dengan adanya hasil penelitian ini dan penjelasan bagaimana cara peningkatan kelancaran ASI, penelitian ini membuktikan bahwa konsumsi daun katuk lebih efektif dibandingkan konsumsi buah kurma. Hal ini dapat disimpulkan dari nilai p-value yang diperoleh bahwa daun katuk lebih efektif terhadap kelancaran ASI.

\section{KESIMPULAN}

Ada efektifitas sebelum dan sesudah mengkonsumsi buah kurma terhadap kelancaran ASI pada ibu menyusui 0-40 hari. Ada efektifitas sebelum dan sesudah mengkonsumsi daun katuk terhadap kelancaran ASI pada ibu menyusui 0-40 hari

Ada perbedaan efektifitas sesudah pemberian daun katuk dan sesudah pemberian buah kurma terhadap kelancaran ASI pada ibu menyusu, dimana pemberian daun katuk lebih efektif dalam meningkatkan kelancaran ASI dibandingkan pemberian buah kurma.

\section{SARAN}

Bagi ibu menyusui diharapkan mengkonsums buah kurma atau daun katuk secara teratur agar produksiSuseno. 2013. Manfaat Tanaman Katuk. ASI nya tetap lancar sehingga ibu dapat memberikan ASI secara eksklusif.

\section{DAFTAR PUSTAKA}

Agoes, A. 2010. Tanaman Obat Indonesia, 0359.2016v37n5Supl2p3519.

Andareto, O. 2015. Apotek Herbal disekitar Anda.Solusi pengobatan 1001 penyaki tsecara alami dan sehat tanpa efek samping, Jakarta: trubus.

Aulianova, R. S. dan Tara. 2016. Efektivitas Ekstraksi Alkaloid dan Sterol Daun Katuk (Sauropus androgynus) terhadap Produksi ASI, Jurnal Majority, 5(1), pp. 117-121. Diakses dari:http://juke.kedokteran.unila.ac.id/in dex.php/majority/article/view/991.

Gartner LM, et al. 2005. Breastfeeding and the use of human milk. Pediatrics, 115(2). doi: 496-506. doi:10.1542/peds.2004-2491.

Hammad. 2014. Khasiat kurma. Solo: Aqwamedia.

Inriani, R. 2017. Capaian Pemberian ASI Eksklusif di Indonesia Baru 54 Persen. Diakses dari: https://www.suara.com/health/2017/08/ 04/031300/capaian-pemberian-asieksklusif-di-indonesia-baru-54-persen.

Muktamar. 2009. ASI Eksklusif Standar Emas, Aman sehat dan berkelanjutan. Diakses dari: http: /kakak.org/home.php? page: artikel \& id:12.

Nurjanah S, Kamariyah N, S. U. 2017. Pengaruh konsumsi ekstrak daun Sauropus androgynous (L) Merr (Katu) dengan peningkatan prolaktin ibu menyusui dan perkembangan bayi di Kelurahan Wonokromo Surabaya, Jurnal Ilmiah Kesehatan, 10(1), pp. 24-35.

Pramita, E. 2017. Pekan ASI Sedunia 2017: Mari Dukung Keberhasilan Ibu Menyusui. Diakses dari: https://majalahkartini.co.id/berita/pekan -asi-sedunia-2017-mari-dukungkeberhasilan-ibu-menyusui/.

Purwanti. 2009. Konsep Penerapan ASI Eksklusif. Bandung: Cendekia.

Santoso, S. dan A. L. R. 2009. Kesehatan dan Gizi. Jakarta: Rineka cipta.

Satuhu. 2010. Kurma,dan olahannya. Jakarta: penebar plus. Selemba Medika. doi: 10.5433/1679- 
Suwanti, E. dan Kuswati. 2016. Pengaruh Konsumsi Ekstrak Daun Katuk Terhadap Kecukupan ASI Pada Ibu Menyusui Di Klaten, Jurnal Terpadu Ilmu Kesehatan, 5(2), pp. 110-237.

Wiji, R. N. 2013. ASI dan Panduan Ibu Menyusui. Yogyakarta : Nuha Medika.

Wulan. 2011. Asuhan Kebidanan Ibu Masa Nifas. Yogyakarta: Gosyen Publishing. 